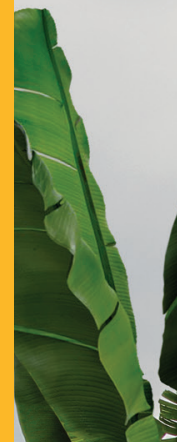

The Journal

\section{of the}

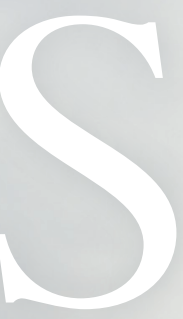

VOLUME 128 No.3 SEPTEMBER 2019

THE POLYNESIAN SOCIETY THE UNIVERSITY OF AUCKLAND NEW ZEALAND

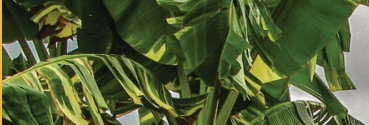

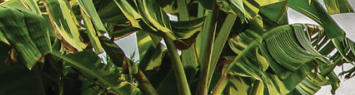

$3 x^{3}$

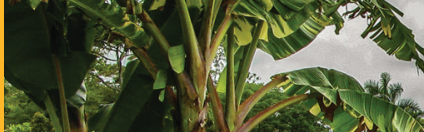

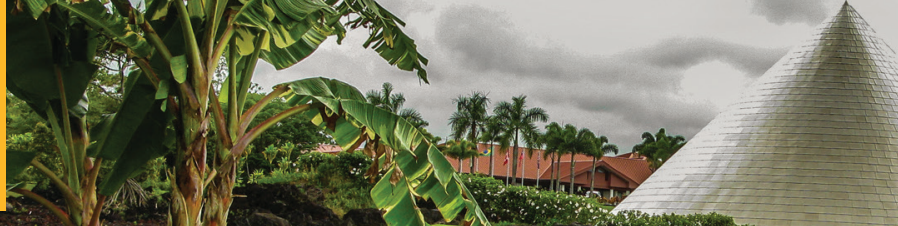

(6)

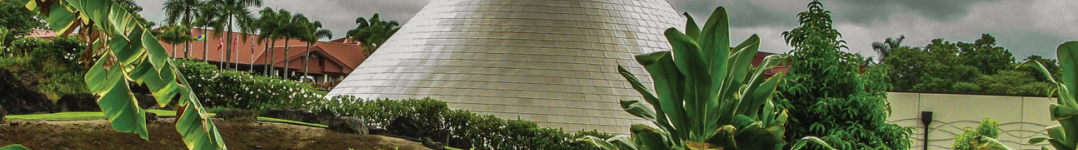

$1012(12)=0$

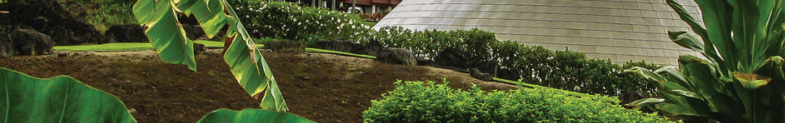

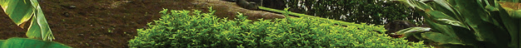

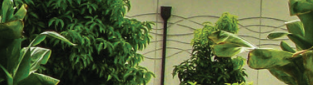

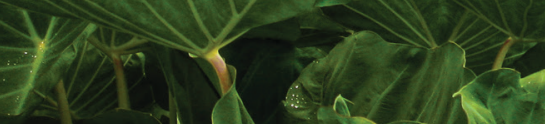




\title{
EYES TOWARDS THE HORIZON: \\ STRUCTURE-FROM-MOTION PHOTOGRAMMETRY \\ ENHANCES UNDERSTANDING OF SHIP PETROGLYPHS \\ FROM RAPA NUI (EASTER ISLAND)
}

\author{
ANNETTE KÜHLEM \\ Institute for Ecosystem Research, Christian-Albrechts-Universität zu Kiel, Germany \\ Commission for Archaeology of Non-European Cultures \\ CHRISTIAN HARTL-REITER \\ German Archaeological Institute \\ Commission for Archaeology of Non-European Cultures \\ NEKA ATAN HEY \\ Independent Researcher \\ SINGA PAKARATI \\ Independent Researcher
}

\begin{abstract}
In this paper we present two petroglyphs of western sailing ships that were recently discovered on Rapa Nui (Easter Island). The far-reaching social ramifications of the arrival of the first Europeans have been discussed in a number of papers, but these newly found images allow for further insight into the effect their arrival had on the Rapanui population. Using structure-from-motion (SfM) macro photogrammetry we created detailed 3D images of the petroglyphs. This helped identify a hitherto unrecognised sense of accuracy and attention to detail employed in the depiction of a European ship by Rapanui artists. Their interest in the construction of European sailing ships, and reproductions thereof, are best understood in the context of the island's isolation and the lost traditions of building ocean-going canoes.
\end{abstract}

Keywords: Rapa Nui (Easter Island), rock art, petroglyphs, structure-from-motion (SfM) photogrammetry, European sailing ships

European sailing ships are known to have made an immense impression on the Rapanui people. Regardless of who and what came on them, and the far-reaching repercussions thereof (cf. Campbell 2003; Pollard et al. 2010), the people of this remote island are described to have had a deep fascination for those giant vessels that first appeared on their shore on Easter Sunday of 1722. The big and complex sailing ships of Europeans were a stark contrast to the small indigenous Rapanui canoes made of sewn-together pieces of 
driftwood that are described to have been used by the islanders at the time of contact (see Hooper 2006: 51). Jacob Roggeveen, the commander of the Dutch fleet that arrived that day, commented that the canoes of the islanders (Fig. 1) were of "poor and flimsy construction" (Corney 1903: 19).

Later descriptions talk about just a few or even no canoes on the island (Corney 1903: 121; Gassner 1969: 19; La Pérouse 1798: 76; Lisiansky 1814: 58). These small canoes were used in the waters around the island, but no mentions are made of big voyaging canoes that could take the islanders to faraway destinations. The Polynesian tradition of open-ocean voyaging was no longer practised by the time of contact (Fitzpatrick et al. 2007: 233). The lack of suitable building materials for ocean-voyaging canoes had led to the isolation of the islanders probably for at least a couple of generations (see Pollard et al. 2010: 568). The Rapanui were thus restricted to their island and the surrounding waters, where for the longest time only the seabirds had been messengers of a world behind the horizon.

In this article we consider some possible reasons why the Rapanui were so fascinated by European sailing vessels and why they incorporated them into their petrographic art. Here we describe two newly discovered petroglyphs and insights gained from the use of structure-from-motion (SfM) photogrammetry and macro photography. We also describe the recorded details of the images and the location where they were found. We argue that the petroglyphs depict European sailing vessels as they were used in the eighteenth and nineteenth centuries and offer some considerations on the importance that ships and their images had for the Rapanui people.

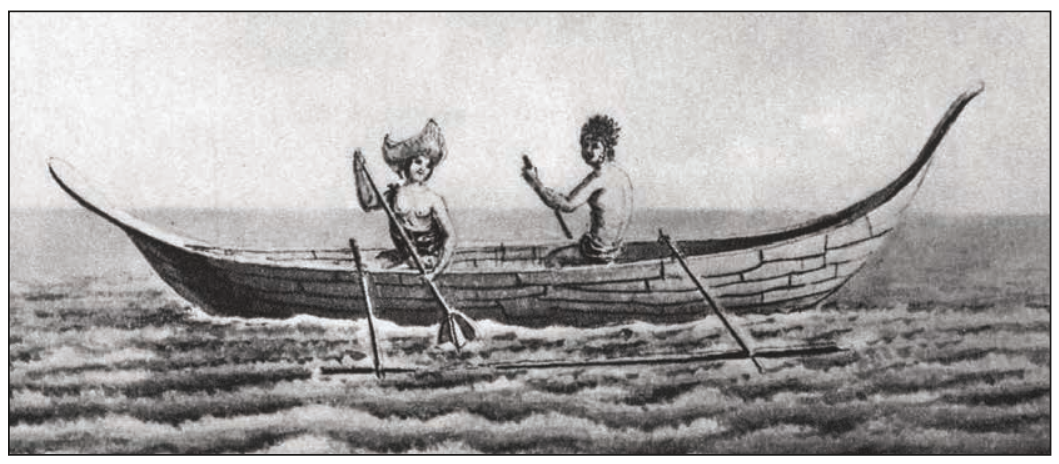

Figure 1. Rapanui canoe (vaka). Note the small sewn-together planks. Original drawing by Blondela, from the Library of Lithographic Services of the Navy, which was included in the atlas of La Pérouse's voyage. 


\section{RAPANUI INTEREST IN EUROPEAN SHIPS}

\section{Efforts to Document and Replicate}

Accounts of the earliest European explorers that arrived on Rapa Nui in the eighteenth century describe how the islanders who came aboard their ships were astounded by the elaborate construction (La Pérouse 1798: 68; Von Saher 1994: 96). All the instruments were scrutinised in detail, and the interest went so far that some of the Rapanui came on board to take exact measurements of anything they could reach, using strings for measuring tapes (Dunmore 1994: 68).

The first missionary to the island, Eugène Eyraud, who arrived in 1864, describes how the islanders insisted that he build them a boat and would not accept that he, as a westerner who came on board a ship, did not have the necessary skills or tools to do so. Regardless of his protests the Rapanui all collaborated in contributing small pieces of wood and gave this project great importance. Due to unsuitable caulking the boat sank shortly after being let to water, much to the dismay of the islanders (Eyraud [1864] 2008: 27-28).

Decades later, after ships calling on Rapa Nui had become a more common event (see McCall 1990; Richards 2008), earthen "boats" (miro o 'one) were built by the islanders. Katherine Routledge (1919: 239-40) was the first to describe these ceremonial structures, during her fieldwork in 1914-15. They consisted of elongated earthen mounds that have the shape of the hull of a ship. In some cases, they were encircled by stones. Their dimensions resemble those of European sailing ships of the eighteenth and nineteenth centuries (ca. $40 \mathrm{~m}$ length, ca. $15 \mathrm{~m}$ width) (Kersten et al. 2010: 131).

The excavation of one of these boats showed that much attention was given to a detailed reproduction of European ships and their technical details (Love 2009). The earthen boats had been dug out of the hard subsoil and were plastered in yellowish clay. A trench surrounding the hull-shaped mound was lined with greyish clay, as if to resemble the water surrounding the ship. Earthen structures represented the fore deck, the captain's station and the poop deck. The miro o'one even carried ballast in the form of wire-wrapped rocks. Obviously never designed to be used as watercraft, they served as a stage for reenacting the behaviour of sailors who came to the island in the nineteenth century. The Rapanui dressed up in garments that they had previously obtained from seamen, the different roles of crewmembers were assigned, commands were shouted and songs about the sailors were composed and performed (Métraux 1940: 351; Routledge 1919: 239-40; Van Tilburg 2003: 141). This has been interpreted as a kind of cargo cult, possibly with the objective of ensuring that more ships, and of course cargo, would arrive at Rapa Nui (Lee 1992: 113; Love 2009). Bartered goods and gifts from the 
sailors were highly sought-after objects. Cloth and iron tools were especially prized by the Rapanui, and the only way of obtaining them was from sailors that arrived at the island. These cargo cults may have been the result of a new demand for these exotic goods. However, Pollard et al. (2010: 575) argue that these cults may be an expression of an interest not only in the cargo but also in the vessels themselves and the strangers that arrived on them.

Overall, the petroglyphs, the accounts of Eugène Eyraud and the construction of the earthen boats suggest that there was an immense interest among the Rapanui to rebuild a sailing vessel—if only there had been sufficient wood to do so.

\section{Rapa Nui's Isolation and Motivations to Leave}

The arrival of the first Europeans on their ships had a profound impact, with Pollard et al. suggesting that "the sheer isolation of Rapa Nui may have amplified the impact" (2010: 568). The interest of the islanders in the construction of sailing ships must be seen in the light of this isolation. The thorough descriptions of Eugène Eyraud about how the islanders harassed him until he agreed to build them a boat shows that they were very interested in the possibilities of obtaining watercraft that could carry them further out to sea than the small sewn-plank canoes that were available.

One possible explanation for Rapanui's desires to obtain or build vessels that would allow them to leave the island is the steep population decline that occurred following initial European contact. Introduced diseases and blackbirding had decimated the island's population (Fischer 2005: 121; see also Maude 1981). As a result, the social, political and religious structures of Rapanui society were severed; much traditional knowledge was lost forever. In 1877 only 111 Rapanui were left. In the first half of the twentieth century the low population numbers led to a wave of escapes from the island, mainly due to traditional marriage restrictions that made it exceedingly difficult to find a partner (see Foerster and Montecino 2012: 206). More specifically, within the Rapanui social code marriage between even distant relatives was not permitted and was often punished by the family. These social rules within Rapanui society are not a product of the twentieth century and must have had particularly dire repercussions in the second half of the nineteenth century, when population numbers were at their lowest.

During the nineteenth century the island was regularly visited by foreign ships (Lee and Horley 2013: 26). They were constant reminders of a world beyond the horizon. The only means of accessing that world were the big sailing ships. The interest in them and their details of construction can thus be seen as an interest in overcoming the island's isolation and the social restrictions that came with it. 


\section{RAPANUI IMAGES OF EUROPEAN SAILING SHIPS}

The depictions of sailing ships in the rock art of the island are further indicators of the significance that western ships had for the Rapanui (cf. Lee 1992: 41, 113). There were painted ship motifs in the Kai Tangata Cave on the southwestern coast and inside one of the houses at the birdman village 'Orongo (Métraux 1940: 272; Routledge 1919: 259; 1920: 433). These painted images can no longer be seen today due to fading in the salty, humid air. The fact that the motif of a western ship was included in the rock art at this very important religious centre implies the importance the objects had for the Rapanui. Lee and Horley (2013: 30-31) emphasise the connection between migratory birds and sailing ships. They stress that both visited the island from afar and - in contrast to Rapanui - had the possibility to leave the island again. Besides the painted images of sailing ships there are a number of petroglyphs thereof. The majority of the depictions were recorded by Georgia Lee (1992) during her petroglyph survey on the island (Fig. 2).

Rapa Nui is not the only Polynesian island where petroglyphs of European ships have been found (e.g., Kikuchi 1964, American Samoa; Millerstrom and

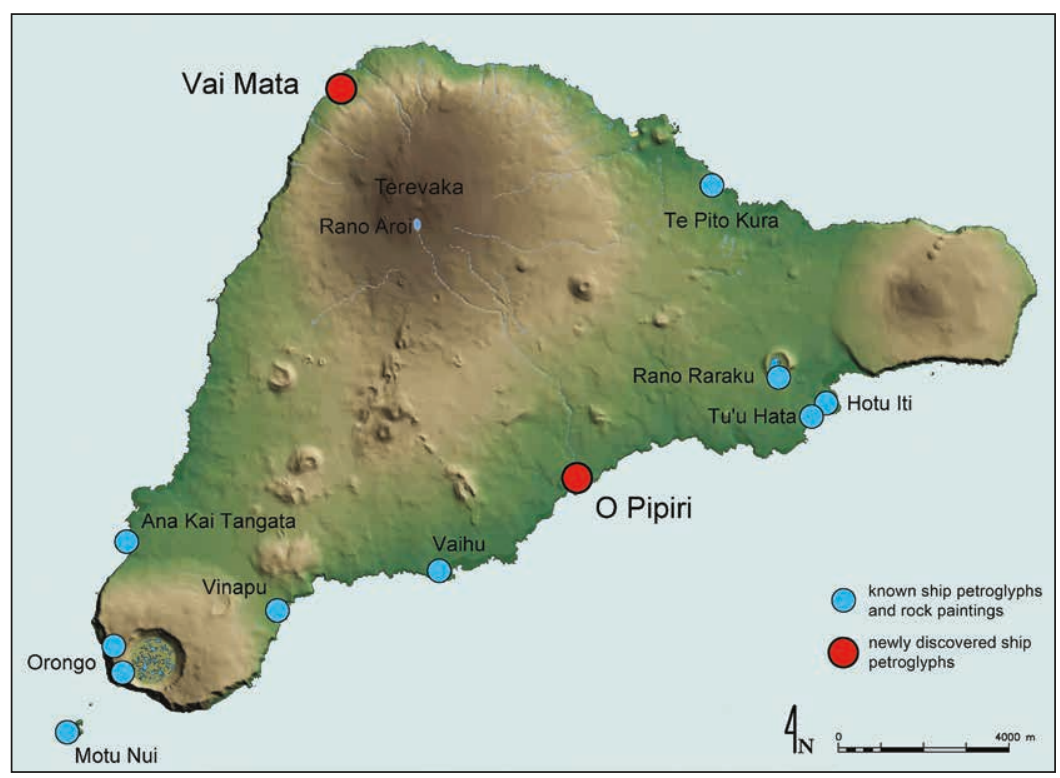

Figure 2. Map of the island with known and newly discovered ship petroglyph sites. 
Kirch 2004, Hawai'i; Millerstrom and Rogers 2005, Marquesas; Stasack and Lee 1992, Hawai'i), but an important distinction has to be made: the other islands where ship petroglyphs have been documented were incorporated into trade networks and/or had large vessels of their own; thus open-ocean seafaring was part of their reality. On Rapa Nui, to the contrary, the necessary technology for open-ocean voyaging no longer existed (Métraux 1940: 204-8). The appearance of an ocean-going vessel on the shore must have had a much deeper effect than on other islands. The geographic isolation of the island also makes it unlikely that Rapa Nui was ever part of a regular trading network, as was the case on many other Polynesian islands (see Hermann et al. 2017; McAlister et al. 2013). So far, there is no evidence thereof. As a Polynesian people that came from a seafaring tradition, the Rapanui were no longer able to go to sea. At the same time petroglyphs of Polynesian canoes, some of them double-hull canoes (cf. Ferdon 1961, Fig. 66a; Mulloy 1975; Lee 1992; Lee et al. 2015), on Rapa Nui show that there was still a collective memory of seafaring.

Probably the best-known petroglyph of a sailing ship on Rapa Nui can be seen in the statue quarry, Rano Raraku, where the image was carved onto the chest of a moai 'megalithic statue' (Heyerdahl and Ferdon 1961) (Fig. 3). Its three masts and the square rigging are typical of European ships; however it has been discussed whether it may be a hybrid with a Polynesian canoe (see Skjolsvold 1961: 353). In lieu of an anchor there is the depiction of a sea turtle that is connected to the ship's hull with a curved line. As with the painted images in 'Orongo, this petroglyph is located within a sacred site. It is the largest known ship petroglyph on Rapa Nui but by far not the only one. The other known rock engravings are much smaller and fainter, made of thin fine lines (see Pollard et al. 2010: 572). The majority depict threemasted vessels as they were used by merchants, explorers and whalers in the eighteenth and nineteenth centuries (McCall 1976; Richards 2008). It is interesting to note that the majority of the ship petroglyphs are found along the south coast of the island whereas the majority of the earliest ships that called at Rapa Nui were anchored off the northeast coast (Corney 1903; La Pérouse 1798; Von Saher 1994). If the petroglyphs were carved to represent a real ship, one that was in sight while the image was being executed, one would expect to find more petroglyphs along the northern coast of the island.

\section{TWO NEWLY DISCOVERED PETROGLYPHS}

Two previously unrecorded ship petroglyphs were recently discovered by the authors: one of them on the south coast, where a number of other such petroglyphs have already been described, and the other on the north coast, where none had been previously found. 
Annette Kühlem et al. 343

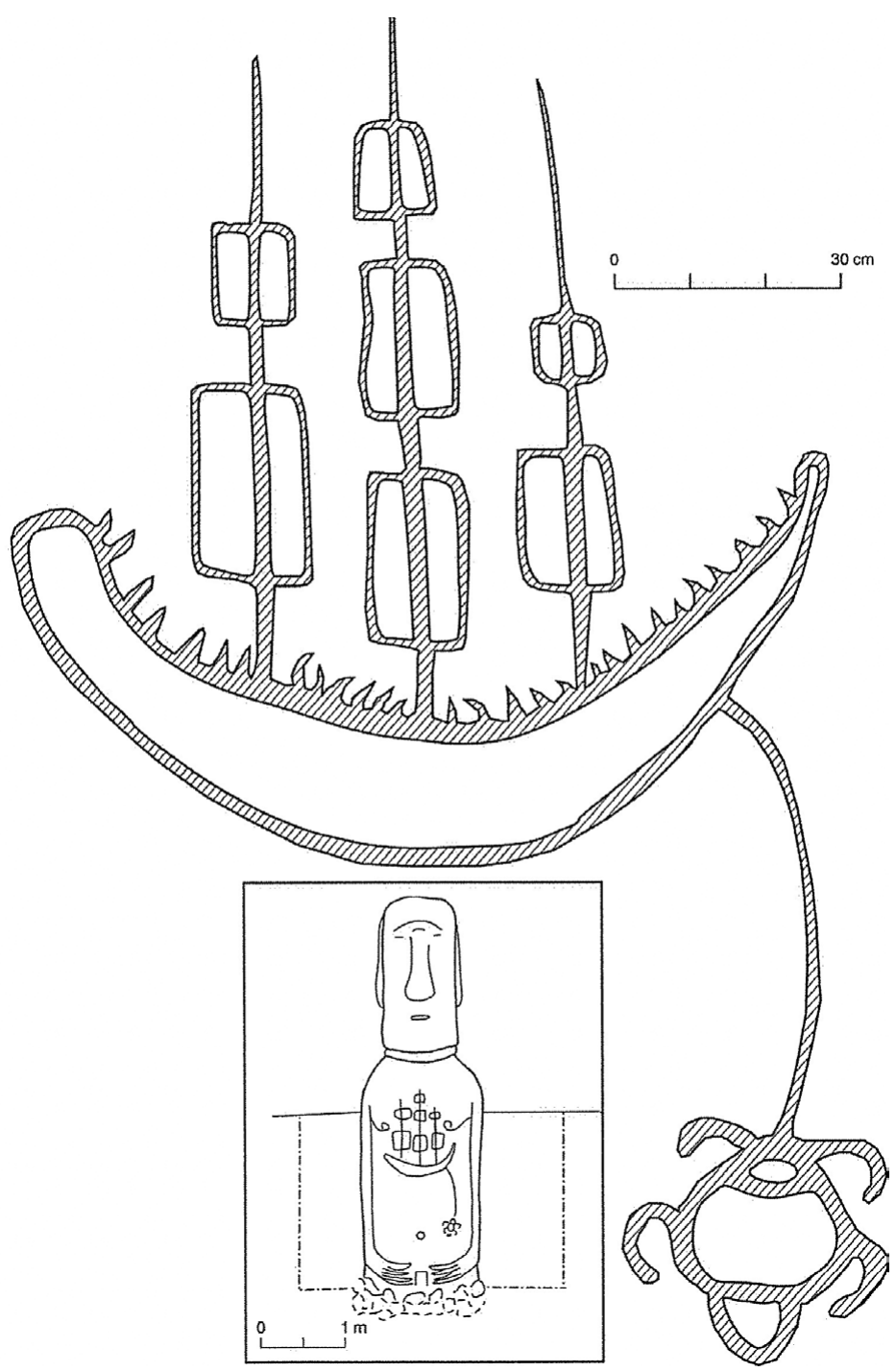

Figure 3. Ship petroglyph on the chest of moai 263 at the Rano Raraku statue quarry. Modified from Pollard et al. (2010) after Heyerdahl and Ferdon (1961). 


\section{The Petroglyph from O Pipiri}

The first newly discovered ship petroglyph was located doing a survey along Quebrada Vaipú, a seasonal creek that runs from the crater lake of the Terevaka volcano to a little bay called O Pipiri on the south coast. The ravine is a collapsed lava tube with the volcanic rock exposed along the sides. On one of these rock faces, almost at the mouth of the creek, a small and very faint petroglyph of a sailing ship was found. The depiction was impossible to capture with conventional photography (Fig. 4a), so it was documented using structure-from-motion (SfM) photogrammetry (see Westoby et al. 2012; Zeppelzauer et al. 2016). Overlapping photos from all angles were taken using a macro lens, before creating a 3D image using the Aspect3D photogrammetry software. These images were texturised with a grid of 1.3 million triangles and revealed more detail than was visible with the naked eye: the depicted ship is three-masted with an anchor and a lot of rigging (Fig. 4b). The lines of the ship, its mast and sails, and the anchor and line are noticeably deeper than the rest of the image (here depicted in yellow). Below the ship there is a series of crossed lines, possibly representing the wave pattern of the sea or a fishing net; these lines - here depicted in white - are much fainter and thinner and with much less depth than the ones of the ship and anchor.

Above the ship there is another set of lines that form a roughly triangular shape. These lines and the lines of the rigging are thinner than the outline of the ship and anchor, but as deep (here depicted in light blue). Seeing the triangular outlines in combination with the vessel, it resembles the profile of the island itself, with the top of the Terevaka volcano creating the uppermost angle (see Fig. 2). Terevaka is the highest point on the island and even today is used by fishermen as a marker for the maximum distance one should travel from shore (Enrique Tuki, pers. comm., 24 April 2017). This is particularly interesting considering the perspective of the artist. All the other ship petroglyphs on the island give the impression that the artist was depicting the view of the ship as seen from the shore. In the case of the three-master in O Pipiri the opposite might be the case: the ship seems to be depicted in its location relative to the island.

In comparing the ship petroglyphs with the images of historical ships that were known to have anchored off Rapa Nui (McCall 1990; Richards 2008), many resemblances can be seen, but no specific ship can be identified with certainty. This poses the question of whether the ship petroglyphs show actual vessels that were anchored off the island or whether they depict the general idea of a ship of which the artist remembers the basic outline. Pollard et al. (2010: 570) proposed that some of the ship petroglyphs show hybrids between Polynesian canoes and European ships, including elements of both vessel types such as a curved hull in the case of the Polynesian canoes and 

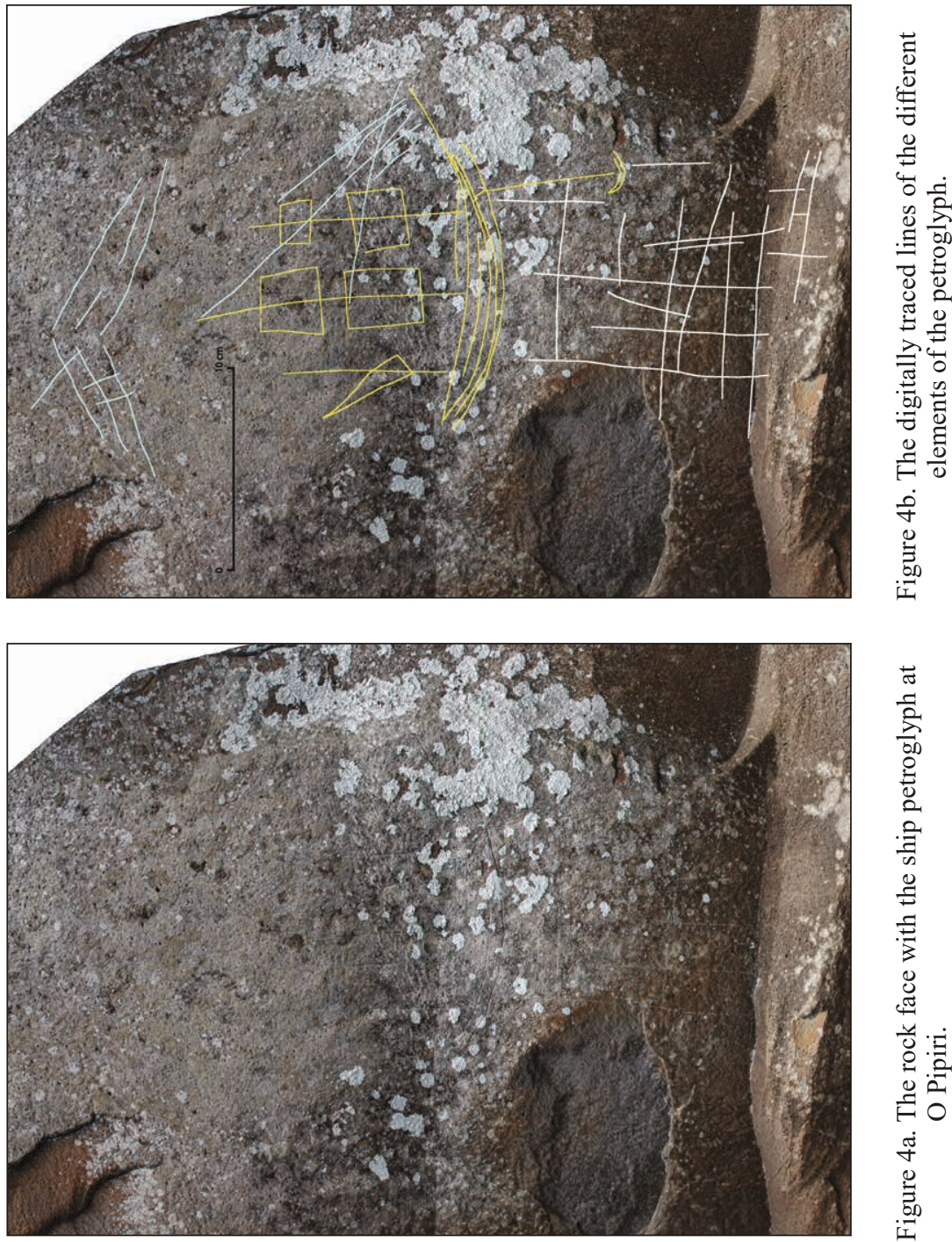


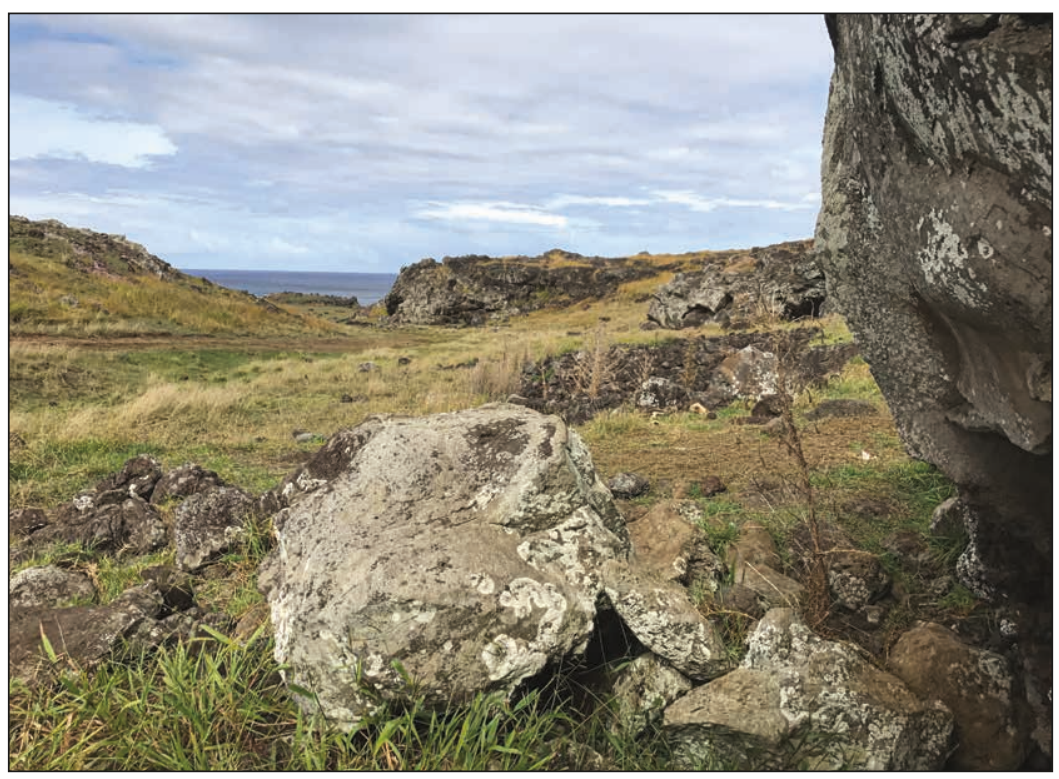

Figure 5. The narrow stretch of sea that is visible from the rock face at O Pipiri.

the three masts in the case of the European ships (Fig. 3). In these cases, the image is clearly not a representation an actual historical ship, but for other ship petroglyphs, this might be the case.

The stretch of sea that is visible from the location of the petroglyph at $\mathrm{O}$ Pipiri is very narrow (Fig. 5). A ship would have had to be anchored exactly in that small visible area for the artist to have a motif in front of his/her eyes while carving the image. The alternative is that the artist did not draw from a visible model but from memory. The second newly discovered ship petroglyph provides some further considerations of that question.

\section{The Petroglyph from Vai Mata}

The second ship petroglyph was found a couple of years ago by two of the authors during a field excursion in the bay of Vai Mata on the north of the island. The location on the north coast is interesting in its own right, since the majority of known ship petroglyphs are found along the south coast. We know that the Dutch expedition in 1722, the Spanish expedition in 1770 and the expedition of La Pérouse in 1786 all navigated close to shore, just off the north coast, for several days, where they must have been well visible from land (Corney 1903; La Pérouse 1798; Von Saher 1994: 97). Thus, this 
is the area where one expects to find ship petroglyphs. However, until the discovery of the Vai Mata petroglyph this had not been the case.

The ship petroglyph of Vai Mata is extraordinary in many respects. Again, the motif is a three-masted sailing ship which resembles the representations of eighteenth- or nineteenth-century ships found along the south coast (Fig. 6). The "canvas", however, is very different; the image is carved onto a flat beach pebble or poro of $22.5 \mathrm{~cm}$ height and $17.5 \mathrm{~cm}$ width. This smooth stone was a surface find in an area with numerous archaeological remains. It forms part of the pavement of one of the boat-shaped houses (hare vaka or hare

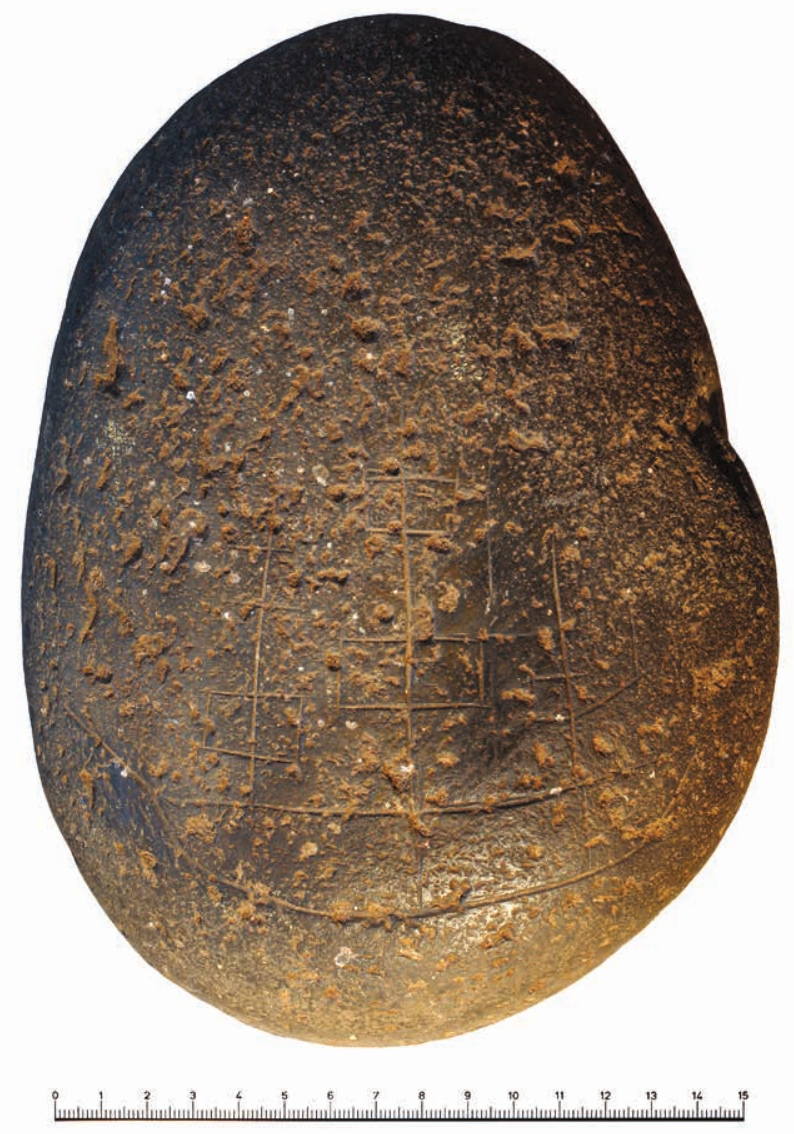

Figure 6. The ship petroglyph on the poro found at Vai Mata (width: $17.5 \mathrm{~cm}$, height: $22.5 \mathrm{~cm})$. 
paenga) of a small hamlet associated with the Ahu Vai Mata. What sets this image apart from the other ship petroglyphs is the fact that it is carved onto a movable object. The only other ship petroglyph for which this is the case is the one on the chest of the moai in Rano Raraku. It is highly unlikely though that the statue was moved for the artist to have a better view of what he/she was trying to represent. For the ship depicted on the poro, however, this was possible, and there are indeed indications that this was done.

Again, three-dimensional imaging of the petroglyph revealed the most interesting information, specifically about the techniques used for the engraving. It can be observed that the lines of the masts were first inscribed lightly and then later grooved using more pressure. Analysis of the depth and width of the cuts shows that the ubiquitous obsidian on Rapa Nui was probably used for those techniques (Peter Kozub, pers. comm., 20 March 2014).

The fact that the lines were drafted before the final execution of the engravings gives an idea that the artist wanted to be exact about what he/she was trying to depict or that he/she was trying to do justice to a certain aesthetic. Lines were not only drafted but also corrected. In the macro image of the lower line of the hull it can be observed that the original line was longer and lower than that of the final grooved image. There are very fine parallel striations where an abrasive material has been used to erase the "incorrect lines" (Fig. 7a). The same can be observed at the central mast, which was originally further to the right (Fig. 7b). The lines were then erased and smoothed over before finishing the image with the mast in the centre of the ship.
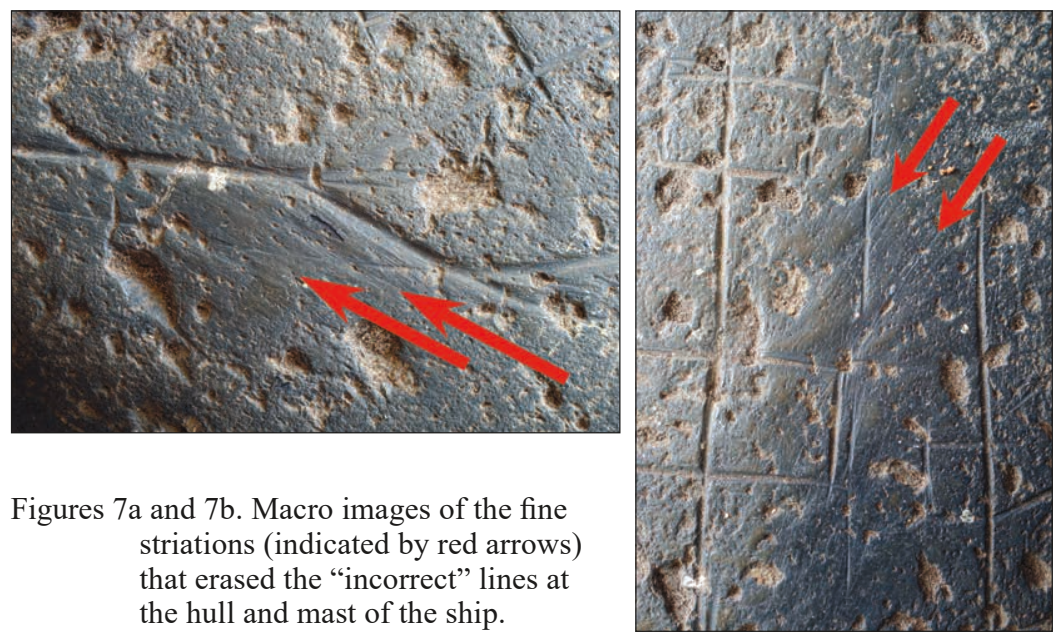

Figures $7 \mathrm{a}$ and $7 \mathrm{~b}$. Macro images of the fine striations (indicated by red arrows) that erased the "incorrect" lines at the hull and mast of the ship. 
There is a desire for accuracy that is transmitted through those fine lines. The petroglyph seems to be an image that did not come from memory but rather was the product of direct observation. The fact that the poro could be taken closer to the ship, held in hand, moved and turned for better perspective gives the artist the possibility to be more exact in the depiction of the object that he/she had in front of his or her eyes.

Bearing in mind how meticulously the Rapanui measured the lengths and widths of the ships they boarded and how precise they were in the reproductions in the form of the miro o one, it seems that this poro is a medium on which someone had made an effort to correctly depict the relative position of hull and mast on a sailing ship. This led us to consider the possibility that the petroglyph from Vai Mata not only shows the idea of a sailing ship but rather an actual vessel that was in sight while the image was carved. The location where the poro was found, on a cliff high above the north coast, where we know from historic records that the earliest ships passed by or even anchored, makes this a plausible scenario. Which specific vessel that might have been is impossible to tell despite our efforts to find a match from the many historic images of the ships that called on Rapa Nui.

$$
* * *
$$

What can be said with certainty is that the sailing ships, the messengers from a world beyond the horizon, held an immense fascination for the Rapanui. The fact that ships were incorporated into the rock art of Rapa Nui and that ship images appear within sacred sites such as 'Orongo and Ana Kai Tangata show their significance. As elsewhere in Polynesia (e.g., Lee 1992: 2), petroglyphs here served mainly to convey religious and statusrelated information and were used as markers of social change. Undoubtedly, the arrival of the European ships brought just that — change with far-reaching implications for the religious and social concepts that had structured the world of the Rapanui on their island. The importance of the sailing ships manifests itself in the island's petroglyphs, the building of earthen boats with such attention to detail and the associated cargo cult rituals that were held on them. Further, Rapanui interest in the construction of European ships, their insistence that the first western inhabitant build them a boat, and the problems arising from low population numbers and strict marriage rules indicate that the Rapanui also had a desire to overcome their isolation. However, the challenges of Rapa Nui's vegetation, specifically the lack of suitable trees, made it impossible to build the ocean-going canoes that would have permitted them to venture across the horizon. To ensure that ships kept calling on the island, new religious manifestations like the cargo cults emerged 
in post-contact times. Attention to detail in depicting European ships seems to have been an aspect of that, as shown by the construction of the earthen boats and efforts to accurately depict observed vessels, as illustrated by the newly discovered ship petroglyph from Vai Mata.

\section{ACKNOWLEDGEMENTS}

We wish to thank Burkhard Vogt, Nikolaus Schlüter, Doris Schäffler, Vaihere Tuki and Michael Patrick Moore for the fruitful discussions, comments and corrections on this paper. The research on Rapa Nui was made possible by the Consejo de Monumentos Nacionales (CAMN) (Santiago de Chile and Hanga Roa), the Corporación Nacional Forestal (CONAF) (Santiago de Chile and Hanga Roa) and Francisco Torres Hochstetter from the Museo Antropológico Padre Sebastián Englert (MAPSE) (Hanga Roa).

\section{REFERENCES}

Campbell, Ian C., 2003. The culture of culture contact: Refractions from Polynesia. Journal of World History 14 (1): 63-86.

Corney, Bolton Glanvill (ed.), 1903. The Voyage of Captain Don Felipe Gonzalez to Easter Island, 1770-1. Cambridge: The Hakluyt Society.

Dunmore, John, 1994. The Journal of Jean-François de Galaup de La Pérouse 1785-1788. Vol. 1. London: The Hakluyt Society.

Eyraud, Eugène, [1864] 2008. Easter Island 1864. Santiago de Chile: Andina Ltda.

Ferdon, Edwin Jr., 1961. Report 3: The ceremonial site of Orongo. In T. Heyerdahl and E. Ferdon (eds), Reports of the Norwegian Archaeological Expedition to Easter Island and the East Pacific. Vol. 1, Archaeology of Easter Island. London: Allen and Unwin, pp. 220-55.

Fischer, Steven Roger, 2005. Island at the End of the World: The Turbulent History of Easter Island. London: Reaktion.

Fitzpatrick, Scott, Jon Erlandson, Atholl Anderson and Patrick Kirch, 2007. Straw boats and the proverbial sea: A response to "Island archaeology: In search of a new horizon". Island Studies Journal 2 (2): 229-38.

Foerster González, Roelf and Sonia Montecino Aguirre, 2012. Rapa Nui: La lepra y sus derivados. Santiago de Chile: Repositorio Universidad de Chile.

Gassner, Julius S., 1969. Voyages and Adventures of La Pérouse. Honolulu: University of Hawaii Press.

Hermann, Aymeric, Lucie Sauzéat, Hervé Guillou, René C. Maury, Catherine Chauvel, Céline Liorzou and Eric Conte, 2017. Combined geochemical and geochronological analyses of stone artefacts provide unambiguous evidence of intra- and inter-island interactions in Polynesia. Journal of Archaeological Science: Reports 13: 75-87.

Heyerdahl, Thor and Edwin Ferdon (eds), 1961. Reports of the Norwegian Archaeological Expedition to Easter Island and the East Pacific. Vol. 1, Archaeology of Easter Island. London: Allen and Unwin. 
Hooper, Steven, 2006. Pacific Encounters: Art and Divinity in Polynesia, 1760-1860. London: British Museum Press.

Kersten, Thomas, Maren Lindstaedt, Klaus Mechelke and Burkhard Vogt, 2010. Terrestrial Laser Scanning for the Documentation of Archaeological Objects and Sites on Easter Island. In F. Contreras, M. Farjas and F.J. Melero (eds), Proceedings of the 38th Annual Conference on Computer Applications and Quantitative Methods in Archaeology, Granada, Spain, April 2010. Oxford: Archaeopress, pp. 125-32.

Kikuchi, William K., 1964. Petroglyphs in American Samoa. Journal of the Polynesian Society 73 (2): 163-66.

La Pérouse, Jean-François de Galaup de, 1798. A Voyage Round the World Performed in the Years 1785-1788. London: Johnson.

Lee, Georgia, 1992. The Rock Art of Easter Island: Symbols of Power, Prayers to the Gods. Los Angeles: UCLA Institute of Archaeology.

Lee, Georgia and Paul Horley, 2013. The paintings of Ana Kai Tangata cave, Easter Island (Rapa Nui). Rapa Nui Journal 27 (2): 11-32.

Lee, Georgia, Paul Horley, Paul G. Bahn, Sonia Haoa Cardinali, Lilian González Nualart and Ninoska Cuadros Hucke, 2015. Secondary applications of rock art at coastal sites of Easter Island (Rapa Nui). Almogaren 46-47: 157-209.

Lisiansky, Urey, 1814. A Voyage Round the World in the Years 1803-1806 in the Ship Neva. London: Longmans.

Love, Charles, 2009. La arqueología en Isla de Pascua no son sólo estatuas: Miro o'one, barco de tierra. Moe Varua Rapa Nui 18: 3-6.

Maude, Henry Evans, 1981. Slavers in Paradise: The Peruvian Labour Trade in Polynesia, 1862-1864. Canberra: Australian National University Press.

McAlister, Andrew, Peter J. Sheppard and Melinda S. Allen, 2013. The identification of a Marquesan adze in the Cook Islands. Journal of the Polynesian Society 122 (3): 257-73.

McCall, Grant, 1990. Rapanui and outsiders: The early days. In B. Illius and M. Laubscher (eds), Circumpacifica: Festschrift für Thomas S. Barthel. Frankfurt am Main: Lang, pp. 165-225.

1976. European contact on Easter Island: Response, recruitment and the Polynesian experience in Peru. Journal of Pacific History 11 (2): 90-105.

Métraux, Alfred, 1940. Ethnology of Easter Island. Honolulu: Bishop Museum Press.

Millerstrom, Sidsel and Patrick V. Kirch, 2004. Petroglyphs of Kahikinui, Maui, Hawaiian Islands: Rock images within a Polynesian settlement landscape. Proceedings of the Prehistoric Society 70: 107-27.

Millerstrom, Sidsel and Richard Rogers, 2005. Sailing ship and dog-poni: Historical petroglyphs on Nuku Hiva, the Marquesas Islands. Rapa Nui Journal 19 (2): 120-26.

Mulloy, William, 1975. Double canoes on Easter Island? Archaeology \& Physical Anthropology in Oceania 10 (3): 181-84.

Pollard, Joshua, Alistair Paterson and Kate Welham, 2010. Te Miro o'one: The archaeology of contact on Rapa Nui (Easter Island). World Archaeology 42 (4): 562-80. 
Richards, Rhys, 2008. Easter Island 1793 to 1861: Observations by Early Visitors Before the Slave Raids. Los Osos, CA: Easter Island Foundation.

Routledge, Katherine, 1920. Survey of the village and carved rocks of Orongo, Easter Island, by the Mana Expedition. Journal of the Royal Anthropological Institute 50: 425-51.

1919. The Mystery of Easter Island. London: Cosimo.

Skjolsvold, Arne, 1961. The stone statues and quarries of Rano Raraku. In T. Heyerdahl and E.N. Ferdon (eds), Reports of the Norwegian Archaeological Expedition to Easter Island and the East Pacific. Vol. 1, Archaeology of Easter Island. London: Allen \& Unwin, pp. 339-79.

Stasack, Edward and Georgia Lee, 1992. The Ka'upulehu petroglyph site. Rapa Nui Journal 6 (4): 82-87.

Van Tilburg, Jo Anne, 2003. Among Stone Giants: The Life of Katherine Routledge and Her Remarkable Expedition to Easter Island. New York: Scribner.

von Saher, Herbert (trans.), 1994. The Complete Journal of Captain Cornelis Bouman, Master of the Ship Theinhoven, Forming Part of the Fleet of Jacob Roggeveen, from 31 March to 13 April 1722 During Their Stay Around Easter Island. Rapa Nui Journal 8 (4): 95-100.

Westoby, M.J., J. Brasington, N.F. Glasser, M.J. Hambrey and J.M. Reynolds, 2012. "Structure-from-Motion" photogrammetry: A low-cost, effective tool for geoscience applications. Geomorphology 179: 300-314.

Zeppelzauer, Matthias, Georg Poier, Markus Seidl, Christian Reinbacher, Samuel Schulter, Christian Breiteneder and Horst Bischof, 2016. Interactive 3D segmentation of rock-art by enhanced depth maps and gradient preserving regularization. Journal on Computing and Cultural Heritage 9 (4): art. 19.

\section{AUTHOR CONTACT DETAILS}

Corresponding author: Annette Kühlem, German Archaeological Institute, Commission for Archaeology of Non-European Cultures, Dürenstr. 35-37, D-53173 Bonn, Germany. Email: annette.kuehlem@dainst.org

Christian Hartl-Reiter, German Archaeological Institute, Commission for Archaeology of Non-European Cultures, Dürenstr. 35-37, D-53173 Bonn, Germany.

Email: c.hartlreiter@gmx.de

Neka Atan Hey, Hanga Roa, Rapa Nui (Easter Island), Chile.

Email: nekaysinga@gmail.com

Singa Pakarati, Hanga Roa, Rapa Nui (Easter Island), Chile.

Email: singapakarati@hotmail.com 